\title{
Grammatical Gender Trouble and Hungarian Gender[lessness]. Part I: Comparative Linguistic Gender
}

\author{
Louise O. Vasvári
}

\begin{abstract}
The aim of this study is to define linguistic gender[lessness], with particular reference in the latter part of the article to Hungarian, and to show why it is a feminist issue. I will discuss the [socio] linguistics of linguistic gender in three types of languages, those, like German and the Romance languages, among others, which possess grammatical gender, languages such as English, with only pronominal gender (sometimes misnamed 'natural gender'), and languages such as Hungarian and other Finno-Ugric languages, as well as many other languages in the world, such as Turkish and Chinese, which have no linguistic or pronomial gender, but, like all languages, can make lexical gender distinctions. While in a narrow linguistic sense linguistic gender can be said to be afunctional, this does not take into account the ideological ramifications in gendered languages of the "leakage" between gender and sex[ism], while at the same time socalled genderless languages can express societal sexist assumptions linguistically through, for example, lexical gender, semantic derogation of women, and naming conventions. Thus, both languages with overt grammatical gender and those with genderrelated asymmetries of a more covert nature show language to represent traditional cultural expectations, illustrating that linguistic gender is a feminist issue.
\end{abstract}

The aim of this study is to define linguistic gender[lessness], with particular reference (ultimately) to Hungarian, and to show why it is a feminist issue. I will discuss the [socio]linguistics of gender in three types of languages, those, like the classical IndoEuropean languages, plus German and the Romance languages, among others, which possess grammatical gender, languages such as English, with only pronominal gender (sometimes misnamed 'natural gender'), and languages such as Hungarian and other Finno-Ugric languages, and Turkish. Japanese, Mandarin, Cantonese, Eskimo, Korean, Filipino, Bengali, Indonesian, and, in fact, a large percentage of the world's languages which have no linguistic or pronomial gender, but make lexical gender distinctions. These languages are called genderless, but, as we shall see, genderlessness is a relative term, as all languages possess some linguistic resources to mark gender distinctions. While in a narrow linguistic sense gender can be said to be afunctional, this does not take into account the ideological ramifications of the "leakage” between gender and sex[ism],' showing, as I aim to show with many examples, that linguistic gender is indeed a feminist issue (see Romaine 1997 on the useful term 'leakage'). Non-linguists and, more surprisingly, even some linguists have sometimes assumed that languages with gender neutral or epicene pronouns (such as Hungarian $o^{\prime \prime} /{ }^{\prime} k$ ' [s]he/they') might be less sexist, but patriarchal societies with genderless languages demonstrate, unsurprisingly, that linguistic gender is not the predominant cause of sexism. So-called genderless languages can express societal sexist assumptions linguistically through, for example, lexical gender, semantic derogation of women, and naming conventions, and, in Chinese, even 
through the graphic system. Thus, both languages with overt grammatical gender and those with gender-related asymmetries of a more covert nature show language to represent traditional cultural expectations. I have to forewarn readers who may expect that this article will narrowly address Hungarian genderlessness, as the title might imply, that they will be disappointed because in order to gain an understanding of the linguistic concept of genderlessness, and in particular within the broader socio-cultural meaning of gender as defined below, it can only be studied as part of both the diachronic and synchronic analysis of grammatical gender systems, so that only the last six pages of this twenty-one page article will specifically treat Hungarian.

My broader project is an interdisciplinary one that lies at the intersection of language and gender and feminist literary analysis (cf. Livia 2001). Here, in Part I of this study, I shall concentrate only on the linguistic manifestations of gender and shall leave for a companion study, the question of the possibility of challenging ingrained gender representations embedded in language, where I shall examine through a contrastive analysis of feminist experimental texts in French, English, languages with grammatical gender and pronomial gender, respectively, and genderless Hungarian (in the latter in works such as Noémi Kiss’s Trans, Noémi Szecsy’s Finnugor vámpir, Attila Bartis’s A Seta, and Agata Gordon's Ezüst boxer and Nevelési kisregény). I shall study, first, how successful such experiments can be in different types of languages, and, second, investigate if translation can function as a feminist act in the re-inscription of a text originally conceived within the feminism of another language and culture. In conclusion, in my larger project I aim to highlight the role of gender within the grammatical system of languages as well as through literary texts, both in the original language and in translation, illustrating that what proclaims itself to be an aesthetic problem is consistently one of sexual politics.

\section{Terminological Complexities of Genus to Gender and the Sex-Gender Binary}

It will be first necessary to define the problematic and much misunderstood term gender, or more precisely, its several sometimes overlapping and confusing uses, due to its complex diachronic development from Lat. genus/genera 'kind, type, kin, stock, family, race' cognate with Greek genos. Many languages of the world have more or less complex formal morphosyntactic classification systems for nouns, such as opposing animate/inanimate, numerical human/non-human, male/female, or even shape-based systems such as small/big, liquid/solid etc., found in sub-Saharan Africa (Aikhenvald 2000, Seifart 2010). In its original and strictly grammatical sense gender is one such classification system, with the term genos (a term also came to be used as a taxonomic rank in the biological classification of living and fossil organisms) having been first used in Greek by the Sophist philosopher Protagoras for the grammatical gender system to indicate whether a referent's gender is masculine, feminine, or neuter through inflectional affixes attached to words, and which involves a complex system of funcionally redundant morphological categories of declensions for nouns, pronouns, adjectives, determiners, which must agree or concord in case, gender, and number with the noun they modify, such as, can be clearly seen in Spanish, which has very obvious morphological exponents of female gender: estas otras alumnas españolas estudiosas 'these other studious Spanish [fem] students,' where four modifiers agree in gender with the feminine alumnas. 
Genos/ genus comes to denote the grammatical gender systems in Greek and in the other older Indo-European languages, such as Sankskrit, Latin, and Celtic, and in modern Romance and Slavic languages, and German, as well as in the unrelated SemitoHamitic languages, such as Hebrew and Arabic. It is this linguistic classificatory meaning of gender, which I shall refer to as Gender 1, which was then this term that was borrowed with a new meaning by the psychologist Robert J. Stoller in the late sixties and borrowed into feminist theory in the nineteen seventies and embraced by fields such as sociology, anthropology, and linguistics, in order to distinguish between 'sex,' to refer to presumably immutable 'real world' biological and anatomical features (such as genitalia) of male and female persons versus the relational socio-cultural understanding of masculine and feminine 'gender' as a socially-imposed division of the sexes that is not inherent, is changeable, and reflects historically and socio-culturally specific ideology of appropriate public and private roles according to person's sex. It is this latter borrowed use that I shall call Gender 2, since it is a meaning derived from Gender 1. To complicate matters further, the Fr. genre, Sp. género, It. genere, etymologically also derived from Lat. genus, but which have come to mean in these languages a literary rather than a linguistic classification, are also at the same time sometimes used in the Romance languages to denote both Gender 1 and 2, so that, for example, in French although attempts have been made to translate gender studies as, variously, étude[s] de genre/sur le genre, all are too ambiguous and the English expression is used by those working in the field. In short, the one term genus has given meaning to three different concepts (which in Hungarian are, respectively, nem, [himnemü and nönemü], társadalmi nem, and müfaj), although it should be noted that most ordinary language users, even academics, continue to treat the two terms sex and gender interchangeably, sometimes with annoyance about why a new term like gender "is needed.” (See Braidotti \& Waaldijk eds. 2008-2009 for a number of studies on the sex/gender distinction in a number of European languages, but unfortunately Hungarian is not among the languages studied them.)

The sex-gender binary and related concepts, such as sexual versus gender identity, are far more complex than it would be appropriate to discuss here, but I hope that the linguistic discussion to follow will make clear the need for such terminological distinctions. Note the succinct evaluation of Gayle Rubin (1975: 159) in her groundbreaking article, “The Traffic in Women: Notes on the Political Economy of Sex," who was one of the first to utilize the term gender in this new derived sense, defining it as "part of the social life that is the locus of oppression of women... [a] socially imposed division of the sexes (2)" (for an accesible overview of feminist perspectives on sex/gender see Mikkola 2008; for more complex issues related to the sex-gender binary, see, for example, Fausto Sterling 2000, Hird 2000, Cameron 2009, and Butler's oeuvre, especially Gender Trouble, whose title I have borrowed in my discussion, who explains how sex and gender cannot be simply opposites, since sexual bodies cannot signify without gender).

\section{Is Grammatical Gender a Linguistic Male Nipple?}

Although, unlike many of his contemporaries, Protagoras did not believe that language was a gift of the gods but rather that it was a human invention, he nevertheless interpreted grammatical gender as biologically and hence semantically motivated, thus necessarily pre-existing language. This lead him to propose, for example, that the feminine Greek 
word for 'anger' could not be correct and should rather be masculine because anger was a male character trait. Protagoras thus gives us our first example of stereotypical grammatical 'gendering,' of confusing the real world category of sex with the linguistic category of gender, but unlike in the overwhelming majority of such cases, here to the detriment of males rather than females.

The controversy over the semantically motivated versus the formal and arbitrary classificatory origin of grammatical gender has persisted from Classical times and became particularly animated among nineteenth-century philologists, who first began to study the diachronic development of the Indoeuropean languages scientifically. The "traditional theory" was represented by the "spiritual” Romantic school of scholars such as Johann Gottfried Herder and Jakob Grimm, who believed that grammatical gender was a conceptual category, a sediment of a state of a prehistoric primitive way of ordering the world through extension of natural gender to inanimates through psychological personification/ mythological animation and sexualization, while Neogrammarians like Karl Brugmann saw it as an arbitrary formal category of syntactical agreement. The question was complicated by the subsequent discovery of Hittite, the earliest attested Indo-European language, which, unlike other Indo-European dialects had a common gender versus a neuter, with the feminine arising only later. Ranko Matasovic (2004) has recently speculated that the dual gender classification of Hittite was then not based on gender but on a count versus mass or animate versus inaminate distinction, and he suggests that it would be useful to compare data in non- Indo-European languages, which would provide fresh external points of reference from which to assess if Indo-European gender was a purely internal development or contact induced. In this context compare, for example, the case of modern Swedish and Danish, which do not distinguish between masculine and feminine grammatical gender but between 'common' and neutral gender, which is, in effect, a distinction between animacy and inanimacy. Compare also the loss of gender in contemporary Swedish spoken in Finland, due to its contact with the genderless Finnish language (see also Ledo-Lemo 2000, Schwink 2004).

Modern linguists consider language as meeting a need for communication rather than as a mythical residue of some ancient and preexistent way of anthropomorphizing nature and thus tend toward the functional view of grammatical gender. István Fodor (1959: 1) in his “The Origins of Grammatical Gender,” points out that it is possible that grammatical gender cannot be accounted for by universally identical causes in all languages and that:

The category of grammatical gender is still one of the unsolved puzzles of linguistics. It is not only with regard to the circumstances of its origin that there has never been complete agreement among linguists, there is still much divergence of opinion as to its function in a particular language system, and, in general as to its definition.

Fodor considers gender as grammatically superfluous as it has no relation to conceptual categories, in contrast other grammatical categories, such as case, time, aspect, number, etc., which do exhibit relationship with conceptual categories. For Fodor the essence of gender as a grammatical category is only its syntactic congruence, that is, that adjectives and other modifiers agree with the gendered noun, such as in Ger. masculine guter Vater versus neuter gutes Kind, thus creating a compact syntactic unit (cf. the early study by Royen 1929, as well as Martinet 1956, Wienold 1967, and Ibrahim 1973 [who considers also gender in Semitic,] Greenberg 1990, Mirkovic et al 2005, Kilarski 2007, Köpke \& Zubin 2009)). Fyodor quotes Charles Bally’s (1952: 45) judgment that the distinction of 
gender is "a linguistic luxury," without relation to logic. Fodor was primarily a Slavisist and Africanist, whose interest in grammatical gender as well as his rejection of it functionality was doubtless sharpened by being a native speaker of Hungarian. Nevertheless, although he does provide a few Hungarian examples, disappointingly he offers no sustained analysis of Hungarian genderlessness.

Greville Corbett (1991) in his volume entitled Gender covers a vast array of over two hundred grammatical gender systems with the goal of showing how they work in languages throughout the world. However, as Mark Aronoff (1992: 606) cogently critiques, he is "almost entirely silent on that hottest of language-based topics, the social construction of gender roles as it relates to biological sex" (a similar criticism can be made of Hellinger \& Bussman 2001, who investigate the linguistic representation of gender in 30 languages of very different structural and socio-cultural backgrounds, but unfortunately Hungarian is not included, although Finnish and Turkish are.) Peter Trudgill (1999) follows Fodor on evaluating linguistic gender as afunctional historical baggage, a luxury in terms of its role in grammar and human communication, following Roger Lass's (1997: 13) rather dramatic coinage, calling it a "linguistic male nipple," which had a reason for its origin but no purpose. He points that no pidgin or creole languages have gender categories (137):

There is no creole language in the world which has reintroduced the category of grammatical gender. A very strong inference is that gender is a category that languages and their speakers can more readily do without than many or most categories.

However, Trudgill, like Corbett, also ignores any ideological ramifications of grammatical gender, eventhough two years earlier Suzanne Romaine (1997: 52), aiming to show why grammatical gender is a feminist issue, published her important "Gender, Grammar and the Space in Between," which deals precisely with what she dubs that "space in-between" where "leakage" between grammatical gender categories and socialcultural gender occurs, the site for the ideological construction of what is female as other. Although Genus or gender, then, likely started out as a classification sytem for nouns to keep specific lexical units morphosyntactically connected, nevertheless, as illustrated with the early example of Protagoras, the formal gender system eventually began to take on psychological effect which had nothing to do with the creation of the category in the first place, and it began to be interpreted, however imperfectly, as a semantic category, gaining in the process some post hoc semantic motivation and interpretation for certain lexical items, based on socio-cultural preconceptions of gender roles. Such fantasized semantic motivation was attributed not only to individual words, as in Protagoras's example above, but also to the presumed superiority or inferiority of whole languages, based on their grammatical gender system, in the in the case of individual words to the diminution of feminine grammatical gender along sexist lines (as will be richly demonstrated in subsequent sections) and in the case of value judgments about languages, along nationalistic lines. Let us first look at an example of each technique - linguistic sexism and linguistic nationalism- as used to claim the superiority of the English language. In the first case, William Lilly and other editors of a 1567 grammar of English claimed that "the masculine gender is more worthy than the feminine, and the feminine more worthy than the neuter" (sig. xvii), thus neatly presenting a rationalization for social hierarchy by analogically conflating grammatical gender with socio-sexual gender. In the second case, of linguistic nationalism, although in English, which originally also had a gender system which had three genders, by the 
fourtheenth century gender had been lost through the phonetic erosion of adjectives, a strictly linguistic evolution common across languages, Frederic W. Farrar (1865: 212, quoted in Klarski 2007: 4), a cleric of the Church of England and Cambridge don who wrote books on philology, interpreted the lack of grammatical gender as proof the superiority of the English language, with the added claim that gender appeared only in primitive languages "at an early childish state of language" (see Curzan 2003 on the linguistic history of gender shifts in English; contrast Platzer 2001, who thinks that the Old English gender system was already by conflicting tendencies towards pronomial gender only). During precisely the same mid-nineteenth century that Farrar was fantasizing his brand of pseudo-philology the distinguished philologist Karl Lepsius (1863), a speaker of German, a language which had not only conserved grammatical gender but all three original Indo-European genders, not surprisingly proposed exactly the opposite view, that only the most highly civilized "races" and "leading nations in the history of mankind” distinguished genders, which supposedly proved that speakers of gendered languages had a higher consciousness of the two sexes, while all other languages without gender were in decline. Lepsius's ethnocentric view of the superiority of the German language fit in well with prevailing ideas about the superiority of European cultures and languages more broadly. While Lepsius used the existence of grammatical gender in German to laud the superiority of his native language in toto, his contemporary, Jakob Grimm, utilized it to promote male superiority, proposing that things named by masculine nouns were earlier, larger, firmer, quicker, more inflexible, active, moveable, creative, etc, while those which were feminine were later, smaller, softer, quieter, suffering/passive, and receptive. Along similar post hoc sexist rationalisations other scholars have claimed, for example, that the Fr. la famille is feminine and l'état 'state' masculine proved that women belonged in the home and men to run the state! Romaine (1999; cf. also Yaguello 1978) in her discussion of these fanciful arguments, points out that while they are ridiculous they do show how over time the noun classes can acquire a certain amount of semantic motivation, and it might be added, collective symbolism, whose dysfunctions, as we shall see in the examples below, can reveal psychological and social conflicts.

The post-hoc diminution of female grammatical gender continues alive in some languages, as shown by Konishi $(1993,1994)$, who studied whether grammatical gender carries connotative meanings of masculinity and femininity for German and Mexican Spanish speakers. In a first study, where he had subjects judge translation equivalents on a semantic differential scale chosen to reflect dimensions of evaluation, potency and activity, he found that speakers of both languages judged masculine words higher, showing that grammatical gender does affect connotative meaning. In the second study he had the two groups of informants judge nonsense words that were marked with gender specific definite articles. For German he found the same results as had S. M. Ervin (1962) on an experiment on the connotations of grammatical gender, using Italian speakers, who judged nonsense words with masculine article higher in potency than those with feminine article; interestingly, however, in Konishi's study Spanish natives did not evaluate nonsense words with the masculine and the feminine article differently. Konishi concluded that even though languages may have similar gender markers, the degree to which the marker is associated with sex distinctions and the resultant transfer of gender connotations may differ. He proposed that it would be important to test other languages 
and dialects within languages and that interesting comparison languages would be French, which, like Spanish, has two genders, but in which the gender is less predictable from the noun ending, and Russian, which, like German, has three genders, but in which the gender is largely predictable from the endings. To date no comparative studies on the connotative properties of gendered words of the sort proposed by Konishi have been conducted, but note the recent article by Elena Kurinski and Maria D. Sera (2011), who investigate how language affects cognition in second language learning, that is, if learning a grammatically gendered language like Spanish changes English-speaking adults in categorizing inanimate objects. The study raises the question whether effects of language on cognition are limited to the learning of language in early childhood or if adults learning a second language will have effect on grammatical gender categorization. In recent years studies several other studies investigating the implications of grammatical gender on cognition and language learning have proliferated but emanating from the discipline of cognitive psychology rather than from [cognitive ethno]linguistics (cf. Vigliocco et al. 2005 and Tight 2006, Ramo \& Roberson 2010, among numerous others).

It should be noted that a language need not possess grammatical gender to make the type of covert sexist judgments studied in the foregoing articles, as, for example, the types of adjectives - smaller, weaker, powerless -- used to characterize feminine nouns in German are exactly the same terms used by Hungarian literary critics (such as those of Nyugat) to describe not nouns, which have no gender, but texts written women as "nöies," with a series of adjectives connoting passivity and lack of power, as gyengéd, finom, puha, lágy, fegyelmezetlen (L’Homme 2007). Note also that English, in spite of having lost grammatical gender centuries ago continues to have a notable group of lexical items with covert grammatical gender, or "connotative gender," including the names of the continents, nations, ships, airplanes, cars, etc., which are perceived as mechanical devices manipulated by males. One of the most outstanding examples of connotative feminization is that of hurricanes referred to as she, on the basis of the presumed similarity of their tempestuousness and unpredictability to that of women. In 1953 the World Meteorological Association started to officially name topical storms after women, a practice that was finally ended in 1979 due to feminist campaign against the sexist overtones of [male] meteorologists providing reports such as "Bad-tempered hurricane Catherine flirted with the Florida coast.” Also prevalent is topographical feminization of continents nations, and cities, as already in the Classical languages, such as in Germania, Britannia, Hungaria, etc. were seen as feminized land/nature in the raw to be cultivated and conquered by males. The topic is widely studied by Sigrid Weigel (1990) in literature, art, and history, but the vulgar covert gender ideology behind this linguistic practice is perhaps most graphically illustrated by the popular joke about "Woman's Age Geography,” variants of which are available today on the internet:

--Between the ages of 16 and 18 she is like Africa, virgin and unexplored [or: half discovered half wild];

--Between the ages of 19 and 35 she is like Asia, hot and exotic;

--Between the ages of 3 and 45, she is like America, fully explored and free with her resources;

--Between the ages of 46 and 56 she is like Europe, exhausted but still has points of interest;

--After 56, she is like Australia, everybody knows it's down there but who gives a damn?

(Other variants of the joke, conflate nations with continents, with lines like: like France. She is half destroyed after the war but still desirable; like Germany, she is half destroyed after the war but still full of hope.) 
The above examples illustrate once again that while grammatical gender likely came about to keep specific lexical units connected, it has clear psychological effect so that once it comes into existence speakers may utilize it in ways which have nothing to do with the original categories (Ibrahim 95). Nevertheless, cross-linguistically metaphoric gender attribution and mental imagery can also become problematic when different languages have contrasting genders for inanimate and abstract terms often used symbolically, like Sin, Death, Life, Fire, Sun, Moon, Sea and the like. This concept of conceptual gender leads to confusing connotations in poetry and in the visual arts, as famously discussed by Roman Jakobson (1959: 237) in relation to the Russian painter Repin, who not realizing that die Sünde 'sin' is feminine in Germany, was baffled by why it had been depicted as a woman by German artists but masculine in Russian. Jakobson recounts also how a Russian child reading a translation of German tales, was astounded to find that Death, to him obviously a woman, was personified as an old man (Ger. der Tod). Similarly, [Sestra Moya-Zhizn] 'My Sister, Life,' the title of a collection of poems by Boris Pasternak, is quite natural in Russian but created enormous translation difficulties for Czech poet Josef Hora in his attempt to translate these poems, since in Czech 'life' is masculine zhian. Or, in a Romance language, consider St. Francis of Assissi's poem "Fratello sole, mia sorella la luna," 'brother [masc.] sun, sister [fem.] moon," which would be incoherent in Germany, where moon is masc. der Mond and sun is fem. Die Sonne (and which is also feminine in Lithuanian but masculine in Greek and Romance, and neuter in Russian). (For a very detailed study on this subject see Köpke \& Zubin 2012, whose results I have not been able to incorporate into this study.)

Grammatical gender equivalents are not only sometimes problematic across languages but also can be so within a language, such as the neuter animates like German das Mädchen 'girl,' das Weib 'woman, wife,' and das Fräulein 'young woman, miss,' where there is mismatch between morphosyntactic gender (where the diminutive ending always requires neuter) and semantic feminine gender, with the result that these nouns are normally followed by neuter pronouns when these appear in close proximity but by feminine ones otherwise. There are, similarly, problems that occur with the so-called epicene (or 'invariable') names of some animals, with a resultant potential ridiculous discrepancy between genus and sex. Some such generic female animals in French are la panthère, la baleine 'whale,' la girafe, while, on the other hand, since l'elefant and le chimpanzé can only be masculine, a French newspaper article had to report on l'elephant or le chimpanzé femelle 'the male elephant/chimpanzee [who is] female' who had just given birth. In German die Katze 'cat' is always feminine, but der Hund 'dog' is always masculine, leading to untold pronomial confusion in a household with a tomcat and a female dog. Der Hase 'hare' is also always male, as it is in Fr. le lievre, but the cognate la liebre in Spanish is female, which allowed my old Romance Philology professor, Yakov Malkiel, to repeat the some joke in each year's class, about how poor hares could only copulate by meeting in the Pyrenees. But it is Mark Twain who most famously and humorously expressed the illogic of grammatical gender in his "The Awful German Language” (1880):

Every noun has a gender, and there is no sense of system in the distribution, so the gender of each must be learned separately and by heart.... In German a young lady has no sex, while a turnip has... horses are sexless, dogs are male, cats are female, tomcats included, of course.... After the student has learned the sex of a great number of nouns, he is still in difficulty, beause he finds it impossible to persuade his tongue to 
refer to things as he and she and him and her, to which it has been always accostumed to refer to it as it (http://www.crossmyt.com/hc/linghebr/awfgrmlg.html)

All the above clashes between formal and semantic gender may seem just an annoyance for language learners or merely humorous, but it soon becomes evident that more is at stake when an expression like Esso's 1959 advertisement slogan Put a tiger in your tank! proved to be untranslatable into Italian, where la tigre is invariably feminine, so that the more powerful-sounding leopardo had to be substituted. It becomes even less humorous when we consider that in a language there may be no way to express the professional role of women, as, for example, in the French masc. le professeur, where a female professor can only be une femme professeur or une professeur femme, and would have to be addressed ungrammatically as Madame, le professeur. Note, however, that in French-Canada Quebec led the way in linguistic reform, making job title feminization official in 1979, and anti-etymological la professeure is an acceptable form, illustrating that language change is possible if there is cultural willingness (Gervais Le Garff 2002, Conrick 2002, 2005, Van Campernolle 2009).

Perhaps ideologically the most vehement argument about the pernicious social power of gendered classificatory systems as serving male bias in language and hence promoting male power have been put forth by radical feminist writer Dale Spender (1980:2), who proposed that language, as the means of classifying and ordering the world becomes the means of manipulating reality, and that when the rules which underlie our language system, our symbolic order, are invalid, then we are daily deceived. Spender universalized from only English examples but four years later Luise Putsch (1984) brought German documentation to bear on the subject of male bias in language, mentioning in her introduction how she felt disincluded because her German passport referred only to its Inhaber '[male] possessor' being a German citizen. In another contemporary study Giorgio Perissinott (1983) studied the Mexican constitution for sentences with supposedly generic hombre standing not only for 'man' but for all humans and found that in sentences like todo homre tiene derecho de entrar en la República y salir de ella 'all men/citizens have the right to enter and leave the Republic' some 85\% of informants understood the sentence from the Constitution to refer only to men. Harro Gross (1991: 76; cited in Pete 2000) cites similar results for the German constitution, where many sentences read as if they didn't apply to women, even in the following especially egregious case, which can only refer to females: Diese beiden Arbeiter nehmen ihren Schwangerschaftsurlaub 'both of these workers [masc.] taken their pregnancy leave.’ A similar study was undertaken by Elke Heise (2000) in German not with pronouns but with masculine lexical nouns such as Lehrer 'teacher' or Bürger 'citizen'which are supposed to be generic, where she asked, sind Frauen mitgemeint? 'Are women included?' to examine what kind of cognitive representations are evoked by these so-called generic masculine nouns versus alternative linguistic forms such as feminized forms (Lehrerin, Bürgerin) and male and female splitting and found unsurprisingly that the generic masculine nouns evoked a disproportionate number of male images, whereas the last led to a balanced number of male and female images (cf. also Doleschal 2000 on the historical development of the generic masculine noun in German). While these last examples refer to lexical gender (to be discussed further below) rather than to grammatical gender the sexist implications are identical. Spender concluded that this linguistic manipulation of reality was why she saw "patriarchy everywhere," that is, that there is no aspect of our lives which is outside patriarchy, and it 
is language and the conditions for its use in turn structure a patriarchal order. Essentially the same view of language as that of Spender as the quintessential arena of symbolic power has been put forth by the far more influential and decidedly non-feminist French male sociologist, Pierre Bourdieu (1989: 2), who held that "symbolic relations of power tend to reproduce and reinforce the power relations that constitute the structure of social space."

\section{Pronomial Gender: "Pronoun Envy” or "Lexical Offense?”}

Because AHEA E-Journal published primarily in English and about matters Hungarian, most readers are likely primarily interested in the differences between pronomial gender in these two languages rather than in more complex grammatical gender, the subject of the previous and longest section of this study. However, the issues yet to be discussed, pronomial gender, lexical gender, and, finally, Hungarian genderlessness, cannot be understood without the historical understanding of grammatical gender, as can be seen clearly from the history of English, which originally posssessed grammatical gender but lost it in the course of its evolution from Old English to Middle English during the eleventh to the fourteenth centuries (Curzan 2003).

While in France and in Germany from the seventies the primary issue much discussed by feminists has been the feminization of professional terminology, as in the example of le professeur, mentioned above, in the English, in contrast, which no longer has nominal gender, the most contested issue about language and gender has been, rather, centered on the so-called generic forms he and man. While English has retained as vestige of its now dead gendered nominal system the gendered pronouns he and she and the possessive his and her in the singular, in the plural it has only the invariable they and their. English also lacks a gender-indefinite, ambiguous, or collective pronoun in sex indefinite contexts such as: If someone / anyone/ a student / has a question [he/she/they] should raise [his/her/their] hand. Ann Bodine (1975; see also Engelhardt 2003) discussed in her now classical article, "Androcentrism in Presciptive Grammar," how they has always been used as default epicene pronoun in English to fill this semantic gap in spite of several centuries of ideologically biased prescriptive efforts to abolish its use and impose the so-called generic he. Bodine traces the history of how through over two centuries [male] grammarians prescribed he but to not much avail because in 1850 an act of Parliament had to be imposed, which declared the gender neutral alternatives he and she and they incorrect the only "grammatically correct" form as he because, as the law stated, the masculine gender was the more worthy and thus deemed to include females. Most grammar books still continue to prescribe this usage today -and surprisingly in written English it is more used today in the U.S. than in Great Britain - but since the 'worthier gender" argument is no longer acceptable, it is now argued that he and she is unacceptable because it is clumsy while they is wrong because it is plural (Baranowski 2002). Suzanne Romaine (2001) discusses how at the moment English usage is very much in flux in written style, with alternatives such as he/she, (s)he, he or she, with each having symbolically different values and attitudes, but that neverthless in her own dialect he remains the only pronoun usable unselfconsciously for generic reference. (It should be noted such "male as norm" rules are in effect not only in Indoeuropean languages, but see also Sa'ar [2007] on how women in Hebrew and Arabic unconsciously avoid feminine grammatical forms to get around this problem.) 
As Anna Livia (2001: 13) reports in her brilliant and readable Pronoun Envy: Literary Uses of Linguistic Gender, among the first feminists to protest the androcentrism involved in equating he and man with the universal were a group of women students at the Harvard Divinity School, in particular because of the he used to refer to God. The women Divinity Students' demonstration elicited a response to the Harvard Crimson, the daily newspaper of Harvard University, from the Harvard Linguistics faculty, who declaired their expertise in asserting that he and man were linguistically "unmarked" for gender and patronizingly assuring the female protesters that "there is no need for anxiety or pronoun envy [italics mine] on the part of those seeking such changes." It is worthwhile to read the whole letter in order to better appreciate its dispariging tone about feminist concern with language and to notice that it was signed by 14 male faculty members, while the three female signators (there being no male faculty in the department at the time) two were graduate assistants and one the department secretary (http://www.thecrimson.com/article/1971/11/16/pronoun-envy-pto-the-editors-of/). It is this episode that Livia recycled with irony for the title of her book to show how battles of gendered language are central to feminist concerns and how such concerns often elicit mean-spirited backlash.

While the Harvard linguistics faculty accused the female divinity students of pronoun envy, linguist Michael Silverstein (1985) coined the much more useful term indexical offense, to refer to the continual emphasis on the masculine as the unmarked conventional gender, which marginalizes women. He proposed that the gendered nature of third-person pronouns could not be treated as the unproblematic reflection of extralinguistic realities, but as a grammatical category whose social valence renders is a salient issue in metalinguistic debates and sexism, or as he puts it: “to 'he' or not to 'he'...thirdperson pronouns thus emerge as a grammatical site for political and ideological contestation and intervention.”

As Silverman eloquently expressed it, and contrary to the opinion of the distinguished all-male Harvard faculty, the use of normative he does perpetuate an oppressive patriarchal order by making females linguistically marginalized and even invisible. Let us recall in the previous section the several studies cited in cognitive linguistics that showed that subject when given masculine nonsense words tended to attribute them with more favorable adjectives than female ones. As discussed by Caleb Everett (2011), studies on the epicene pronoun he and generic man[kind] in English show similar results, such as speakers overwhelmingly construing both as masculine (see Niedzielski 1992 on how young boys, in particular, overwhelmingly assume male gender for generic masculines) . Everett in his own study sought to go one step further and presented English speakers, who possess gendered pronouns, and Karitiana speakers (a languagee spoken by approximatly 300 people in Northwest Brazil), who rely heavily on epicene pronoun usage, with non-gendered stick figure stimuli and asked them to suggest names for the figures. He found that names chosen by English-speakers were more androcentric in their construal of gender-neutral stimuli than were names chosen by speakers of Karitiana. Because the latter language has so few speakers, for further verification of his findings Everett is currently collecting data from Mandarin, another language with only epicene pronouns. A comparison with Hungarian would obviously be most interesting in this context.

\section{Lexical Gender Trouble}


We have looked at grammatical gender and pronomial gender, and we now turn to lexical gender, doing so in that order, because all languages that possess grammatical gender will also inevitably have both pronomial and lexical gender, while all languages, even if they do not, like Hungarian, have either grammatical or even pronomial gender, possess lexical means for expressing gender. In short, lack of grammatical or pronomial gender does not mean that the concept of gender cannot be communicated, as in every language, to a greater or less degree, it is communicated by lexical means. In this sense, although there are many languages without grammatical gender there can be no linguistically genderless language.

Lexical gender refers to the vocabulary rather than to the grammar of a language, to the property of non-linguistic male or femaleness as encoded in the lexical meaning of individual nouns such as in male and female, man and woman, or by the addition of an affix, as in prince-princess. Lexical gender is particularly important in the structuring of vocabulary where the sexual distinction is biologically or culturally salient, as in household animals (bull-cow, stallion-mare, goose-gander), kinship terminology (fathermother, son-daughter, aunt-uncle), some titles and positions (king-queen, widowwidower, steward-stewardess, tailor-seamstress). Grammatical gender languages tend to have significantly more such sexually differentiated lexical pairs, as in Ger. VetterKusine but Eng. invariably cousin, Sp. maestro-maestra, Eng. teacher, while in English most personal nouns are unspecified for gender. Neverthless, many like pedestrian, consumer, patient, person, neighbor etc., are invariable treated as masculine when the person is not specifically known and are followed by a masculine anaphoric pronoun, while terms like babysitter or school teacher would be treated as feminine. Even more important from a linguistic sexism perspective is that even among such pairs as above few are truly symmetrical, as there is usually some level of semantic derogation of the female terms (on semantic derogation see Schulz 1975). For example, in almost all cases where the feminine form of the pair is marked by the suffix - ess, the marked feminine word is derogatory, as in poet-poetess, which is why women today insist on being called [woman] poet and why even the Academy Awards are no longer awarded to Best Actress but to Best Female Actor. Similarly, a governor governs a state while a governess governs only children, so that the sentence *Governess Jane Smith traveled with her children and their governor would be an impossibility. And of course a major commands troops while a majorette is a nubile young woman in a miniskirt who twirls a baton, to cite only two of hundreds of such possible pseudo-symmetrical pairs. And compare the serious asymmetry between master and mistress, where the latter unless specifically collocated with of the house can only connote a kept woman. Compare also feminine divorcée, whose male counterpart, divorcé, although listed in dictionaries, isn't used, or needed, as, after all, divorced men are deemed to become bachelors again. Nor, by the same token does spinster a male counterpart, as men can also remain bachelors to any age, and also do not get nasty collocations, as Baker (2002) illustrates in his article, “'Eligible Bachelors' and "Frustrated' Spinsters.” Note also feminine terms that have no male analogue at all, such as seamstress, where its male pseudo-equivalent tailor has higher prestige, or housewife, formerly with no male equivalent and the new creation househusband used only jokingly or disparagingly (with attempts to soften it with the stay-at-home-dad). And of course for the endless terms of woman of ill repute such as slut, tart, floozy, prostitute and the like there are no male equivalents (as shown by the 
marked form, male prostitute). Very occasionally, new non-gendered words such as spouse and sibling (originally an anthropological term created in 1903) have been created to be able to avoid the clumsy use of two gendered words in contexts where that distinction is not salient. While such coinages are rare they have been able to enter the language without undue controversy because they meet a need that did not have gendered socio-cultural implications.

Social Gender refers to a subcategory of lexical gender, according to which people assume 'male' or 'female' for certain words which are not linguistically marked, based on their stereotypical and historical classification, as in the examples babysitter and school teacher, above. Social gender is a non-linguistic category that reflect social and cultural stereotyped assumptions of male and female character traits, abilities, and what are appropriate social and professional roles. Social gendering is particularly evident in the sex-biased semantic loading of various low-level female job titles versus higher-level male ones. It has to do with stereotyped assumptions about appropriate roles, irrespective of whether a language has grammatical gender, and underlying is always the principle of “male as norm,' except in positions of low prestige, so that seamstress, as above, or cleaning woman have no real male equivalent, while in culturally male professions deviation will often require formal marking even in languages with gender systems, such as woman pilot, lady author, and much more complex Ger. weiblicher Pilot 'female [but adj. in masc. to agree with masc. noun]pilot,' männliche Krankenschwester 'male [fem. adj.] nurse [but literally 'sister to the ill']. A good example of uncertainty in gender assignment based on evaluation of prestige of a given position is provided by Mario Wandruszka (1969: 173), who cites the example of the translation into five European languages of the term 'cook' in an aristocratic household in Daphne de Maurier's Gothic novel Rebecca, which translators render as feminine and two as masculine, depending on how they interpret the importance of the position. Many higher-status occupations terms such as lawyer, doctor, or scientist will frequently be pronominalized by the male specific pronoun he where secretary, nurse, school teacher by she. Note the following examples, where it is social gender that account for the totally predictable choice of pronoun in the first example and for the surprise in the second (Nissen 1985: 31):

-- The nurse has an important role to play in patient care; she has more contact with the patient than the doctor does.

-- I went to the dentist yesterday. What a day!

What did he say?

Well, she said that if I go on like this, I'll have to get false teeth very soon. Thus, while in principle nouns like doctor and nurse have no gender-specifying function they are assigned gender as a reflection of normative societal conditions, with such conditions tied to a degree to parameters of time, so that, as noted by Lyons (1977: 311, quoted in Nissen 31) in 1900 'lady typist' was common in employment ads, where it would never be used today, whereas, on the other hand, woman/lady doctor is still prevalent even after a hundred years of women being in the profession, doubtless because the profession of typist has been demoted as women entered it but the doctor profession has not.

The problem of high status professions, the subject of a significant number of scholarly articles (Sabatini 1985, Conrick 2002, 2005, Gervais-le Garff 2002, Elmiger 2008) can be illustrated in more detail by doctor, a professional term that is a particularly 
problematic across languages, because while the number of female doctors has steadily increased in the last hundred years languages have not caught up with societal changes. In English, where doctor is not linguistically marked for gender anymore than is, say, teacher, neverthless in British National corpus Romaine (2001: 159) found it marked as lady/woman/female doctor 155 times to male doctor a mere 14 times. Italian has both an invariable masculine il médico but feminine dottoressa, as can be seen in the titles of the two Holocaust memoirs by two female camp doctors: Ruth Weidenreich, Un medico nel campo di Auschwitz. Testimonianza d una deportata (1969), and Sima Vaisman. La testimonianza di una dottoressa deportata ad Auschwitz. In the first title una deportata had to be added as an alternate title to avoid the memoir being read as the testimony of a male doctor. Also for Italian, Alma Sabatini (1985) showed how a headline in II Messagiero was unable to deal linguistically with the political candidacy of a female doctor, producing an ungrammatical jumble of male and female terms: Elda Pucci, medico, 51 anni, fanfaniana, la candidata à sindaco 'Elda Pucci, doctor [m.], 51 years old, a supporter [fem.] of Fanfani, candidate [fem.] for mayor [m.].'

In Spain, while in the nineteen seventies (Hampares 1978) Spanish dictionary insisted on only masculine el médico being correct (along with other masculine-only prestige professions. such arquitecto, científico, crítico, dermatólogo, diplomático, dramaturgo, farmaceútico, físico, geógrafo, geólogo, ingeniero, piloto, psicólogo, zoólogo) today, in spite of some vacilation between médico and médica all these terms are fairly freely used in the feminine with $-a$. Mercedes Bengoechea (2006: 153) has been monitoring the Spanish press for sexist usage and her general conclusion is that at century's turn some rapid changes, most from oral language, and the resistance in formal registers to the dictates of the Royal Spanish Academy have show that language is rapidly taking account of fundamental societal changes, making place for the visibility of women. She traces the popular influences, including the anti-etymological feminization of the masc. testigo 'witness' (with its roots in Lat. testes, since originally only men could be witness), especially to the influence of Almodovar's film Mujeres al borde de un ataque de nervios, where a charactered said porque soy testiga de Jehová 'because I am a Jehova's Witness [fem.]. The Spanish language has also in writing been enriched by a new virtual vowel @, or the arroba, used to be inclusive of females in mixed gender plurals, so that instead of writing estimados amigos one might correctly address a letter today toestimad@samig@s.

In French as spoken in France masc. le medecin and le docteur are still the norm, as I well recall from reading a novel in which the protagonist accompanies her father to a clinic, where it took me several paragraphs to realize that the doctor being described was a she, at the point the first pronoun appeared. However, in French, too, mixed forms are beginning to appear, as in Le Monde (Ma 16, 2007): le docteur [masc.] Laurence Framois... une médecin [fem. article + masc. noun]. When a famous personality, Dominique Desanti died on 8 April, 2011 newspaper obituaries had a a time with the gender of her various professions, alternating and mixing genders for écrivain [e], historien[ne], romancier[e], but always fem. resistante and always masc. auteur. In another instance of adjectival confusion even even the conservative Le Figaro, had to note the ridiculousness of sentences such as: Le chancelier allemand est descendu de l'avion en tailleur vert en escarpins roses et le president Chirac s'est incline pour baisemain 'The German chancellor [masc.] descended from the plane in a green suit and rose 
colored slingback heels and President Chirac bent down to kiss [her] hand (Houssemaine 2006:14). Particularly interesting in late 2011were the Socialist Primaries in France, where two of the six candidates were female and were referred to as la candidate Segolene Royale and Martine Aubry, la maîre de Lille and première secretaire du Parti Socialiste (the same newspaper also wrote la presidente de Chile but used masc. écrivain 'writer,' even in an article about a women's forum).

The question then raises itself, why is it that while French-speaking Quebec, as already mentioned, was in the forefront over thirty years ago with feminization of job titles, and with terms like professeure, chirurgienne, écrivaine, auteure, maitresse de conférences, and even sapeuse-pompière 'fem. firefighter' in common use there, that in France there is still so much resistance and hesitation. At least part of the answer is to be found in the still significant power of the French Academy, which immediately declared itself against any language reforms in relation to the feminization of professions. It is the forty "immortals," the lifetime members of the Academy who have the task of acting as an official authority on the language and of revising the Academy dictionary and determing what contemporary locutions should be admitted. A woman, Marguerite Yourcenar, was admitted only in 1980, some one hundred years after the first woman had been proposed. And in this case the dead head of one powerful individual, Maurice Druon, can be felt on the whole language. Druon, the "Perpetual Secretary" of the Academy who was admitted in 1960 and died in 2009 at the age of 90, was known as a cultural conservative who argued from a position of enormous power against relaxing the historical gender assignments given to French nouns. He claimed it foolish political correctness, for instance, to allow a woman serving as a government minister to be referred to as la ministre rather than le ministre because the word was according to him male, no matter who held the post. It should be noted that, in contrast, the Spanish Royal Academy admitted the feminized la ministra in the nineteen seventies. Druon labelled dictionaries that admitted such words as dictionnaires poubelles 'garbage can dictionaries' (Houssemaine 2006: 14; Weber 2009).

Lack of syntactical agreement between speaker's cultural gender and grammatical gender represents the exclusion of the female gender from the public lingustic space even when individual women begin to be allowed in, with the subordination of their gender reflecting the limits of their participation in cultural production (Sa'ar 2007: 410).

\section{Is Hungarian a Genderless Language and Does It Matter?}

As we have seen, Hungarian, as well as other Uralic languages like, Estonian, Lappish and Altaic, as well as Turkik lack the grammatical gender that historically all Indoeuropean languages in their geographic surrounding possess, or possessed at an earlier stage (on Finno-Ugric see Laakso 2005, on Turkish see Braun 2000, on Finnish and Turkish, Engelberg 2000). Hebrew and Arabic also have gender but many other languages do not, from Basque within Europe, to many languages in the world, such as Chinese, Japanese, Korean, Yoruba, Malay, Tagalog, Quechua, Georgian, Hawaiian, among others. Since none of the cultures in which these languages are spoken are distinguished by having less androcentric societies than those of Europe, this in itself seems significant indication that grammatical genderlessness does not embue a society with special consideration for females. It is therefore surprising to read that Mühlerhäuser 
and Harré (1990: 238), authors of a linguistic account of pronomial gender in English, lament that:

[they] have not been able to find any work devoted to the question of whether there are sexist assumptions built in to languages that do not have grammatical, and hence neither natural nor conventional gender, such as Hungarian... we can only deplore the lack of research into the psycho-linguistics of sex-marking in a culture as close to ours as Hungary.

More research on genderless languages would be welcome, especially because as Ferris (1988: 277) has pointed out, language and gender research arising from Western feminist theory, has over-relied on examples from Indoeuropean languages (with, however, Chinese and Japanese now developing important studies, some of which are useful for drawing parallels with Hungarian; cf. Tan 1990, Chan 1996, Fan 1996, Inoue 2002, 2006.)

Neverthless, for linguists to except to find potentially "fewer sexist assumptions" built into such languages is optimistic. As we've seen in the last section, even in languages possessing grammatical gender sustained cultural gender trouble is to be found primarily in lexical gender, and even in languages as closely related to one another as the Romance languages the level of gender-conscious language reform undertaken has been very different, showing that underlying differences are likely caused not be language types but by differing local language ideologies.

A fascinating example of just such language ideology at work in the case of Hungarian is the little known fact that during the during the Hungarian language reform, whose most intense period was between 1790 and the 1820s, there were reformers who sought to create a feminine third person pronoun to make up for what they felt was a lack of the Hungarian language vis-à-vis German. Ferencz Kazinczy (1795-1831), a cultural policymaker and the leading figure of the Hungarian language reform recognized the special significance of language standardization and reform and the development of a literary language in the service of nationalism and of modernization and for a while he did not oppose the proposal, as he called it, for the nöstényités 'femalization' of the Hungarian language to “elevate' it to the level of European models, although in the end he did stop short of endorsing such proposals (Dömötör 2006 , Kiss 2009):

Nem idegen tőle a nyelvi rendszerbe való beavatkozás gondolata sem: a nyugati nyelvek, elsősorban is a német bűvöletében élve nem emel szót az ellen az ötlet ellen, hogy a magyarba bevezessek a nemeket, kiküszöbölve nyelvünkben ezt a nagy "hiányosságot.” Ami amikor ennek megvalósitásával, a "nőstényitéssel" találkozik, visszakozik, s ettöl kezdve a neologia újabb túlkapásai ellen is hadakozik. What is equally fascinating is that during Japanese modernization a full century later than in Hungary, essentially the same arguments surfaced for the need to introduce a gendered third person pronoun in Japanese, as well, its lack being perceived as lack, defect, and sign of cultural backwardness (Inoue 2002: 397).

There is to date, to my knowledge, no fully developed account of the Hungarian genderless pronomial system within a comparative context. Fodor (1959), a native speaker and specialist in genderlessless in African languages unfortunately only glancingly mentioned Hungarian, pointing out that while Hungarian ki-mi and Finnish kuka-mikä do not distinguish gender in the third person they do distinguish between animates and inanimates, and he analyzes such pronouns not as belonging grammatical gender proper but as being lexical items. In the context of the animacy hierarchy it interesting to note the apparently increasing the use of $o$ for inanimates in sentences such as $o^{\prime \prime}$ lesz az? when, for example, a salesperson might point to an object in a store to ask perhaps in an pseudo-friendly way 'is this the one [you wanted]?' That is, Hungarian, at 
least in a marked [pseudo]friendly usage $o$ has crept into the language instead of $e z$ or $a z$ 'this, that' to designate inanimates, or in linguistic terms, inanimate entities of absolutely no personal significance in such expressions have moved up the animacy hierarchy to be personified (on the animacy hierarchy and gender, see Dahl 1999). This fact and that, at the same time, in sentences like Aki megtudná oldani a feladatot az nincs itt '[the person] who could solve the problem is not here,' or Akik szeretik a zenét, ök sokat járnak koncertre 'those who like music go to concerts a lot' ö/ök'[s]he/they' has begun to replace $a z$ 'that', felt to be inanimate, although from from the point of view of normative grammar the animate pronoun is analyzeble as hypercorrect usage (personal communication: Klara Sándor). That is, even the animacy-inanimacy distinction is beginning to fade. Just when this transition started and how widespread its usage and to what age group has not been adequately investigated and in my preliminary investigations my informants give wildly differing opinions. Interestingly, in English exactly the opposite process is occuring where from substandard and Black English the use of inanimate which for who is spreading. This creeping extension of $o$ to inanimates is of tremendous interest in relation to gender if we recall, as I mentioned early in this paper how some theories hold that even in grammatical gender languages the original distinctions were between animacy and inanimacy, a point to which modern Swedish and Danish has returned by having reduced its three genders to two, masculine and feminine together versus neuter, that is, animate versus inanimate.

Another analysis of Hungarian pronouns from a comparative perspective very different from that of Fodor's is that of Peter Trudgill (1999: 139), who, as I discussed earlier, supports the idea of the "male nipple" afunctionality of grammatical gender. He cites examples from Hungarian syntax to show how it gets along fine without even third person pronouns for their potential functions like disambiguation and reference tracking (that is, to figure out where a third person $o$ in Hungarian refers to a previous 'she' versus 'he'). He cites the example in English John kissed Bill and then he ran away, where, since both the subject and object are masculine, the tracking function is no help and one has to say John kissed Bill and then Bill ran away. Trudgill also gives another comparative example, where in English John kissed Mary and ran away versus John kissed Mary and she ran away is translated as János megcsókolta Marit és elfutott and János megcsalta Marit, aki elfutott.

Lacking grammatical gender and pronomial gender, in Hungarian gender then can only be expressed as a semantic category, which Fodor mentions only glancingly and Trudgill's study dealing strictly with the virtues of Hungarian genderless pronouns, does not take into account. On how Hungarian lexical gender and in particular social and connotative gender works there are to date only a handful of publications, from which I will draw some of the examples in my following discussion (Pete 2000, Kegyesné, Szekeres Erika 2006, Nagy \& Patti 2006). First of all, let's recall the earlier discussion of how in gendered languages landmasses, countries, and cities are feminized, which I illustrated with a particularly egregious sexist joke. We can note for a start that lacking grammatical gender has not prevented Hungarian from evoking the same sort of feminized personalization, as illustrated in the now evergreen hit song from István a Király, sung by Mikos Varga, Szeretem öt, a ven Europát, a gyönyörü nöt 'I love her, old Europe, the beautiful woman,' which contains lines like megszülte hütlen gyermeket...elvetett...'bore a thankless child, aborted, 'etc. (the full lyrics can be found at 
http://www.zeneszoveg.hu/dalszoveg/1301/varga-miklos/europa-zeneszoveg.html, where we can read that some of the commentators find this song "more beautiful" than the Hungarian national anthem; see also Huszar 2011: 130-146).

Like in all languages Hungarian has some gendered lexical primitives for some animals (csödor-kanca, gunar-lud, kakas-tyuk, can-szuka, bika-tehén), a set of gendered words for not only for the universal kinship terms, but with special terms for older and younger brother and sister, and a few non-productive forms, such as Latinate medikusmedika, doktorandus-doktoranda, although the feminine of these seem to be gaining ground only lately, and some oddities like the feminine kollegina flanking masc. kolléga, a peculiarly marked, usually slightly deprecatory variant of the more usual kolléganö, but just like in gendered languages where the presence of any masculine among any number of feminines makes the group masculine, so in Hungarian the plural is Doktoránduszok Országos Szövetsége. The model, except for a few such limited exceptions, is that nouns don't show gender in principle all the following could refer to either gender but in fact the hidden social determinants as to how the following nouns will be interpreted as male to female illustrates that social gender is what is primary for interpretation:

A futballista sokat olvasott A tanuló elöttem szállt fel a villamosra A modell az átlagosnál magasabb volt (these and a few of the foregoing examples come from a useful article available on the internet, "A társadalmi nem megjelenési formái a magyar nyelvben,” whose author I was unable to track down). In terms of professional terms in principle all terms from eladó 'sales[person]' to, for example, kutatómérnök 'research engineer' to neprajztudós 'ethnologist' as able to refer to either gender but it is very doubtful that they all do so in people's imagination.

Some other gendered or genderless features of nouns include:

--Having no grammatical gender, Hungarian never has to struggle with forms like 'the male elephant who is female gave birth in the zoo,' but yet it does have compound possibilities for some animals, as in himelefánt 'male elephant' and nöstényelefánt 'female elephant.'

--While in Hungarian özvegy 'widow[er]' can refer either to a male or female but szalmaözvegy 'straw widow' is usually male while víg 'merry' or szép özvegy 'beautiful widow' can only collocate with a female.

--There are some low status and very female occupations for which there are as yet no male equivalent, or where these are still in flux, such as varrónö 'seamstress;' mosónö 'laundress,' bejárónö ‘cleaning woman [always in a private home],' nővér 'nurse' (but literally 'sister'), fejönö 'milking woman, 'and it is doubtful if flanking takaritónö 'cleaning woman’ one could say takaritó ember? 'cleaning man;' or flanking apolónö 'nurse’ one could say apoló? férfi ‘male nurse’ or apoló, without gender marking. -- Ovónö 'woman kindergarten teacher,' where there is no *ovó[férfi] 'male kindergarten teacher,' the term ovóbácsi 'uncle/elder male kindergarten [teacher]' (like the stay-athome-dad) is only tolerable because of its pseudo-intimate tone. Both genders can also be referred to as ovópedagógus 'kindergarten pedagogue,' although the term is more often applied to males.

--There are a number of other occupational terms that have an insecurity in naming, as shown by an excess of variants recorded, as in munkás 'worker, manual laborer,' flanked 
by nőmunkás, munkásnő, munkásasszony, női munkás, női munkaerő (for statistical occurences of these and some of the other terms see Nagy \& Patti).

There are three forms of $n o$ ' 'woman' for forming feminized lexical items: The compound -nö added to professional terms, where it serves a suffixal function, serves in principle as absolute reference, as in orvosnö, doktornö, tanárnö, in opposition to -né in relational suffix position, as in Kovácsné 'the [wife] of Kovács;' and nöi before the noun and all of these are productive. While the most common is -nö, as in eladónö 'saleswoman,' titkarnö 'woman secretary,' once we get into status professions the same problems emerge as we have seen in French invariable masculine le professeur. Tanár is a job traditonally done for a long time by both sexes, and when I am be addressed directly I am called tanárnő. However, if someone were to inquire what my profession is and I replied tanárnö [vagyok] '[I am a] female teacher,' they would assume that I am a secondary school teacher. As a university professor I can say only: egyetemi tanár vagyok, with *egyetemi tanárnő vagyok impossible. Or, alternately I can be a profeszor, but, as one of my former students reports, whenever she mentions her new yorki profeszor all listeners always and only that assume she is speaking of a male professor.

Particularly problematic are the female terms in Hungarian for 'author,' where one can in principle say irónö 'writer+woman', nőiró 'woman+writer,' női iró 'womanish+ writer,' and iró 'writer' (and similarly for költönö 'poet+woman,' versus nöi költö 'womanish+ poet, and költö 'poet') but there is so much fluctuation that someone sensitive to the issue can no longer use any form unselfconsciously. All these terms were used at some time in the last century, as, for example, as early as about 1909 Ilona Váradi (who had to publish in Nyugat under the male pseudonym Vándor Iván) founded the Magyar irónők kör while in 1939 Dr. Jób Báhegyi published a book entitled Magyar nöirok. On the other hand, in a 2003 Ph.D. dissertation Ilona L'Homme had the title A nöi irók helye az irodalmi diszkurzusban. 1900-1945, the variant that to my ears sounds the most demeaning. Very recently the feminist writer and activist Anna Lovas Nagy in an interview on the recent publication of her book Verazélet referred to herself as both irónö and nöi szerzö. Finally, another feminist writer, Noémi Kiss was vehemently recently dubbed as iró, ket gyermek anyukája 'writer [with no female gender marker], the mommy of two children'(Centrifuga Sept 22, 2010), terms which presumably she insisted on, and the ungendered Gobbi Hilda szinesz 'Hilda Gobbi actor' also appeared in another periodical (HVG.hu 2011.Aug. 24). The overabundance of variants and the fact that Noémi Kiss purposely chose to call herself ungendered iró and that nö $i$ - carries a serious level of markedness and hence potentially of unseriousness (cf. nöipilota 'a woman who [happens to be/is a] pilot') illustrates how uncertain these forms still are and that while many people now hesitate in which form to use only a few do so with adequate sociolinguistic reflection. One such person who does is the writer Viktoria Radics (2007) who in a cogent review of a novel by Ildikó Lovás reflects on topics that only women write about by using both nöiró and irónö in the same sentence with specific intent: csak a férfiak el szokták felejteni, hogyan kerül a tyúk az asztalra. Nőiro ezt is tudja, irónő pedig ábrázolja. Szivestül belestül. 'It's that men tend to forget how the hen gets on the table. The female writer knows this too, and the woman writer depicts it, [including] the heart and the guts, ie., completely [the lame translation cannot do justice to Radics's clever punning feminist literary analysis]. Finally, consider the same distinction in the title of the recent work by Anna Borgos and Judit Szilágyi, Nőirók és irónők (2011). I 
asked Anna Borgos what was the significance of this title and I quote here her reply at length because I think it illustrates so beautifully what I have termed the "Grammatical Gender Trouble" of my title, showing that indeed "genderless" Hungarian, suffers from as much lexical gender trouble as does, say, gendered French with invariable écrivain, but feminine anti-etymological écrivaine now butting in, and with only masc. auteur allowed in Continental French but fem. auteure used in Canada, now for some thirty years. Here is Anna's considered reply to the distinction between nöiró and irőnő (the translation is mine):

The question is not simple. The original idea for the title came from a sentence in an early critique by Ernő Osvát, a sentence which reads: "What an awkward/disagreeable word this is: what is an irónő [writer+woman] like? Even without knowing her, an irónö is someone charming!" According to Osvát, the nöiró [woman+writer] is primarily a writer, for whom writing pushes her femininity into the background, while in the case of the irónö the gendered aspect is emphasized, but with a troublesome connotation of dilletanism. However, if I had not read this quote from Osvát I would probably judge these words just the opposite: with nöiró the 'woman' aspect is emphasized more as a prefix, while in irónó it is just a supplemental affix added to [masc.] iró 'writer.' The nö 'woman' part of nöiró is at the same time something more general; in the case of irónö the nö part simply refers to her biological sex. In literary analysis I prefer to use nöiró. And then of course there is also iró, a term that normally still elicits a masculine image.

Finally, in addition to -nö and -né there is the compound -asszony that sometimes alternates with -nö (as even in the rare munkásasszony, above), and, for example, in elnöknö versus elnökasszony (26\% to $75 \%$ ), and with a similar insecurity between igazgatónö and igazgatóasszony. In English in woman writer versus lady writer, the second, like to some ears nöi iró, is always from at least mildly to very condescending. An interesting sidelight here is that English also uses -lady for a condescending amelioration, as in cleaning lady for cleaning woman (but only cleaning man), a form (takaritóasszony) that virtually doesn't occur in Hungarian. In Hungarian the woman versus lady distinction is just reversed, as it is -nö that has lower status and is hence more general and is used generally for occupations whereas -asszony is used with titled positions, such as miniszterasszony 'minister+lady,' allamtitkárasszony 'undersecretary+lady,' and even séfasszony 'chef+lady,' used as vehemently opposed to an ordinary szakácsnö 'cook+woman'). Instead of the -asszony, the unmarked form, as in iró above is also used, as in Dr. Dávid Ibolya, országgyulési képviselö 'Dr. Ibolya Dávid, Member of Parliament.' Nevertheless, it seems clear that none of these forms with (too) many variants can be employed today totally unselfconsciously, as is evident from the example of how Member of Parliament Katalin Szili was addressed at a formal event in Szeged in the recent past as Szeretettel köszöntjük az elnökasszony urat! 'We welcome Madame Speaker, Sir!

\section{Engendering Female Visibility, Or Is Linguistic Equality Possible?}

Proposals for feminist language reform such as those for inclusive pronouns and professional terms, as discussed above, cross disciplines -- linguistics, politics, sociology, psychology, journalism, etc. -- and are inserted into politicized and strongly ideological debates. While reformists propose that change is necessary because women referents remain linguistically and hence culturally 'invisible,' cultural conservative critics of reform claim forms like generic he or male-only designations for professional terms belong to "natural" language and are too engrained to change. However, many such forms have in actuality been kept alive or even been created by prescriptive grammarians 
and academic dictionary makers through the centuries. Critics also like to accuse reformers of linguistic engineering, political correctness, or even of "feminazism." To cite one sole example, Keith W.Percival (1981), in an article entitled "Sex and Gender in Natural Languages,” after claiming that changes won't work anyway, gives as his final argument that attempts by government or special interest groups to legislate linguistic usage inevitably causes resentment, using as his example of linguistically onorous legislation presumably akin to feminist reforms a Nazi decree in Alsace in 1941 to make inhabitants use Heil Hitler instead of bon jour. In fact, both the reformists' and the cultural conservatives' points of view represent linguistic engineering, or what Deborah Cameron (1995) has famously come to call verbal hygiene, the attempt to regulate and especially to arrest change in language. However, the aim of one group is to protect the andocentric worldview in the name of historic or aesthetic purity and of the other group to demand the right to auto-designation, that is to determine the right how to be called and to demand cultural visibility.

The questions that arise from the foregoing discussion is what effect, if any, feminism has has actually had on language change and in what way in languages with different linguistic gender systems. Or, as Mühlerhäusler and Harre (1990: 230) asked, are there linguistic reforms that could stand some chance of ameliorating what is surely an unacceptable state of affairs. Languages differ in terms of amount of sexism they display and in how they do so, which implies they require different types of reforms to engender female visibility. There are two main reformist tendencies, degendering (or gender neutralization) and engendering (or feminization). The first is generally preferred by languages without grammatical gender, such as English, and includes examples like replacing waiter and waitress with server, or actually creating new neutral forms such as flight attendant, firefighter. Languages with gender systems, like the Romance languages and German, generally prefer introducing feminized forms of terms that would in fact be linguistically natural in that language but have been normatively prohibited, such as Sp. la ministra, discussed above. In German, for example, where female -in ending is well established in word formation some female visibility is achieved by adding it to terms that didn't have it before, such as Soldatin 'female soldier,' Bischöfin 'female bishop,' Dirigentin 'female conductor.' German also uses a number of other techniques such as dual forms, as in the movement to replace man 'one' with man/frau, and the unusal use of the collective as an alternative to the masculine, as in das Präsidium 'presidency' instead of der President, as well as rather wordy double modifications like weibliche und männliche Chirurgen/Piloten/Politiker, and new creations like Krankenpleger 'male caregiver' and Mitglied des Reinigungspersonals 'member of the cleaning staff.'

Hungarian is in a peculiarly problematic position because having no grammatical gender it might be expected that preferred non-sexist forms would be genderless ones, as in the striking example of Noémi Kiss, iró es ket kis gyerek anyukája. However, at the same time, Hungarian has richly developed lexical gender with compounds of the type nöi irö, nö iró, irónö, which offers additional possibilities but in very confusing connotative jumble, so that, for example, doktornő is a female doctor but a nödoktor can be a male who is a nögyogyász 'gynecologist,' while a female gynecologist is nö[i] nögyogyász. Engendering is never totally successful even in grammatical gender languages, as I witnessed in the recent Socialist Primary campaign in France, where Segolene Royale declared at one point: je suis la meilleure candidate [fem.], which in 
effect meant she was declaring herself better only than the other female candidate, Martine Aubry, since the feminine cannot be extended as a universal to cover the four male candidates. On the other hand, had she called herself le meilleur candidat it is unclear if she would have universalized or simply masculinized herself, which is also still part of the problem with Noémi Kiss, iró in genderless Hungarian.This is why radical feminist theorist Monique Wittig (1986: 65) was against the use of feminine forms and for the suppression of gender in language, eventhough she was writing only from the perspective of French. She proposed that there really is no masculine and feminine but only "le general," which is confused with the universal, plus the always marked feminine. Or as she put it: "Gender is the enforcement of sex in language, working in the same way as the declaration of sex in civil status." From a more linguistic perspective, as Romaine discusses $(2001: 158,170)$ it is clear that language, culture and social practice constantly interact, and that representations of women or men are embedded first in language, with language playing an active role in the symbolic positioning of women as inferior to men, sometimes in obvious ways, at other times in more subtle ways, with language thus holding the key to challenging and changing male hegemony.

As a final coda to this long discursion, let me recall that when linguist Carmen Rosa Caldas-Coulthard in a 2006 article she submitted for publication in Sao Paulo designated that the generic reference would be the feminine autoras the editor rejected her article on the grounds that it made it seem like men had ceased to exist and that there were only female researchers and authors.

\section{BIBLIOGRAPHY}

Abe, Hideko. 2004. "Lesbian Bar Talk in Shinjuku, Tokyo.” In Deborah Cameron \& Don Kulick, eds. The Language and Sexuality Reader. London: Routledge: 132-40.

Aikhenvald, Alexandra. 2000. Classifiers: A Typology of Noun Catgorization Devices. Oxford: Oxford UP.

Aronoff, Mark. 1992. Rev. of Greville Corbett, Gender. Language 68.3: 605-610.

Baker, Paul. 2008. “'Eligible’ Bachelors and 'Frustrated' Spinsters: Corpus Linguistics, Gender, and Language.” In Kate Harrington, ed. Gender and Language Research Methodologies. New York: Palgrave: 73-84.

Baranowski, Maciej. 2002. "Current Usage of the Epicene Pronoun in Written English.” Journal of Sociolinguistics 6.3: 378-397.

Bengoechea, Mercedes. 2006. “Lento deslizamiento del género gramatical feminino.” Spanish in Context 3.1: 1390-157.

Bodine, Ann. 1998 [1975]. “Androcentrism in Prescriptive Grammar: Singular 'They’, Sex-Indefinite 'he, and 'he' or 'she'. In Deborah Cameron, ed. The Feminist Critique of Language. London: Routledge: 124-40.

Boroditsky, Lera. 2003. “Linguistic Relativity.” Encyclopedia of Cognitive Sciences. Lynn Nadel, ed. NY: Nature: 917-22.

Braidotti, Rosi, \& Berteke Waaldijk. 2008-2009. The Use and Abuse of the Sex/Gender Distinction. Maing of European Women's Studies. 9 volumes. Utrecht: Athena, Utrecht Universitait. 
Braun,Friederike. 2000. Geschlecht im Türkischen: Untrsuchungen zum sprachlichen Umgang mit einer sozialen Kategorie. Vienna: Harrassowitz.

Butler, Judith. 1990. Gender Trouble: Feminism and the Subversion of Identity. New York: Routledge.

Bussman, Hadumod \& Marlis Hellinger. 2003. "German. Engendering Female Visibility in German.” In id. eds. Vol. 3: 141-174.

Caldas-Coulthard, Carmen Rosa. 2002. "Caro Colega: Exclusão e invisibilidade.” Discurso y Sociedad. Revista multidisciplinaria de Internet 1.2 http://dissoc.org/ediciones/v01n02r

Camereron, Deborah. 1995. Verbal Hygiene: The Politics of Language. London: Routledge.

Chan, Marjorie K. 1996. "Gender-Marked Speech in Cantonese: the Case of SentenceFinal Particles je and jek. Studies in Linguistic Sciences 26.1/2: 1-38. Repr. In Marlis Hellinger \& Hadumod Bussmann, eds. 2002. Amsterdam: John Benjamins. . 1998. "Gender Differences in the Chinese Language.

Conrick, Maeve. 2005. "Madame le professeur ou Madame la professeure” ?: The Debate on Titles and Terms of Address for Women in a Professional Context." In Stuhlmann, A. \& P. Studer, eds. Language - Text - Bildung, Sprache - TextBildung. Frankfurt am Main: Peter Lang: 37-46.

Conrick, Maeve. 2002. "Language Policy and Gender Issues in Contemporary French.” In Salhi, K., ed. French in and out of France3: Language Policies, Intercultural Antagonisms and Dialogue. Oxford, Bern, Peter Lang: 205-35.

Corbett, Greville G. 1991. Gender. Cambridge: Cambridge UP.

Curzan, Ann. 2003. Gender Shifts in the History of English. Cambridge: Cambridge UP. Dahl, Östen. 1999. “Animacy and the Notion of Semantic Gender.” In Barbara Unterbeck \& T. matti Rissanen, eds. Gender in Grammar and Cognition. The Hague: Mouton: 99-116.

Doleschal, Ursula. 2002. "Das generische maskulinum im Deutschen. Ein historischer Spaziergang durch die deutsche Grammatikschreibung von der Renaissance bis zur Postmoderne.” Linguistics online 11.2/02 http://www.linguistikonline.de/11_02/doleschal.html

Dömötör, Adrienne. 2006. “A nyelvújitás.” In Ferenc Kiefer, ed. Magyar nyelv. Budapest: Adamémiai Kiadó: 385-400.

Elmiger, Daniel. 2008. La feminisation de la langue en francaise et en allemand. Querelle entre specialists et reception par le grand public. Paris: Honore Champion.

Engelberg, Mila. 2000. “The Communication of Gender in Finnish.” In Marlis Hellinger Marlis \& Hadumod Bussman. Gender Across Languages 2. Studies in Language and Society 9. Amsterdam: John Benjamins: 109-132.

Engelhardt, Maike. 2003. “Generic Pronouns in English: Rules versus Ideology.” In José Santaemilia, ed. Género, lenguaje y traducción. Valencia: Universidad de Valencia: 160-171.

Ettner, Charles. 2002. "In Chinese, Men and Women are Equal - or -Women and Men Are Equal? In Marlis Hellinger \& Hadumod Bussman, eds. Gender Across Languages. Amsterdam: John Benjamins: 29-54.

Ervin, Sue M. 1962. “The Connotations of Gender.” Word 18: 249-61. 
Everett, Caleb. 2011. “Gener Pronouns and Thought: The Ligature Between Epicene Pronouns and a More Neutral Gender Perception.” Gender and Language 5.1: 133-152.

Fan, Carol C. 1996. “Language, Gender and Chinese Culture.” International Journal of Politics, Culture and Society 10.1: 95-114.

Ferris, Catherine S. 1988. "Gender and Grammar in Chinese: With Implications for Language Universals.” Modern China 14.3: 277-308.

Fodor, István. 1959. “The Origins of Grammatical Gender.” Lingua 8: 1-41, 186-214.

Gervais-le Garff, Marie-Marthe. 2002. “Liberté, Egalité, Sororité: A New Linguistic Order in France” Women and Language 25.2: 1-7.

Greenberg, Joseph H. 1990. “How Does a Language Acquire Gender Markers?” On Language: Selected Writing of Joseph Greenberg. Ed. Keith Denning \& Suzanne Kemmer. Stanford: Stanford UP: 241-270.

Gross, Harro. 1991. “Frauensprache-Männersprache.” Einführung in die Germanische Linguistik. Munich: XXXX: 170-176.

Hampares, Katherine. 1978. "Sexism in Spanish Lexicography.” Hispania 59: 100-109.

Heise, Elke. 2000. "Sind Frauen mitgemeint? Eine empirische Untersuchung zum Verständnis des generischen Maskulinums und seine Alternativen.” Zeitschrift für Sprache und Kognition 19.1-2: 3-13.

Hellinger, Marlis \& Hadumod Bussman. 2002. “Editors’ Introduction “ in id. Eds. Gender Across Languages. Studies in Language and Society 9. Amsterdam: John Benjamins1-25. . 2001-2003. Gender Across Languages. The Linguistic Representation of Women and Men. Amsterdam: John Benjamins. 3 vols.

Huszar, Ágnes. 2011. A nő terei. Budapest: L’Harmattan Kiadó.

Ibrahim, Muhammed Hassan. 1973. Grammatical Gender. Its Origin and Development. The Hague: Mouton.

Inoue, Miyako. 2002. “Gender, Language, and Modernity: Towards an Effective History of Japanese Women's Language.” American Ethnologist 29.2: 392-422; repr. in id. Vicarious Language: Gender and Linguistic Modernity in Japan. Berkeley: U of California P.

Jakobson, Roman. 1959. “On Linguistic Aspects of Translation.” In R. A. Brower, ed. On Translation. Cambridge: Cambridge UP: 2332-39.

Kegyesné, Szekeres Erika. 2006. “Nyelvi szekizmus és szexista nyelvhasználat a magyar nyelvben.” In id. \& Simigné, Fenyő Sarolta, eds. Sokszinü nyelvészet.

Alkalmazott nyelvészeti gender-kutatás. Miskolc: Miskolci Egyetem Alkalmazzott Nyelvśzeti Tanszḱke: 91-100.

Kilarski, Marcin. 2007.On Grammatical Gender as an Arbitrary and Redundant Category." History of Linguistics 2005: Selected papers from the $10^{\text {th }}$ International Conference on the History of the Language Sciences (ICHOLS, X), 1-5 September, 2005. Ed. Douglas Kibbee. Urbana-Champaign/Amsterdam: John Benjamins: 24-36.

Kiss, Jenő. 2009. “Kazinczy, az Akadémia és a magyar nyelv ügye.” Magyar nyelv 103.3: 257-262 http://www.c3.hu/ magyarnyelv/09-3/kissj_093.pdf 
Konishi, Toshi. 1993. “The Semantics of Grammatical Gender: A Cross-Cultural Study.” Journal of Psycholinguistic Research 22.5: 519-534. . 1994. "The Connotations of Gender: A Semantic Differential Study of German and Spanish.” Word 45.3: 317-327.

Köpke, Klaus-Michael \& David A. Zubin. 2009. “Genus.” In Elke Hentschel \& Petra M Vogel, eds. Handbuch der deutschen Morphologie. Berlin: de Gruyter: 132-154.

Köpke, Klaus-Michael \& David A. Zubin. 2012. "Mythopoeia und Genus.” In Susanne Güntherer, Dagmar Hüpper, \& Constanza Spiess, eds. Genderlinguistik. Sprachliche Konstruktionen von Geschlechtsidentität. Berlin: de Gruyter: 377406.

Kurinski, Elena \& María D. Sera. 2011. “Does Learning Spanish Grammatical Gender Change English-Speaking Adults' Categorization of Inanimate Objects?” Bilingualism: Language and Cognition 14: 203-220.

Laakso, Johanna. 2005. Our Otherness: Finno-Ugrian Approaches to Women's Studies. Vienna: LIT Verlag.

Lass, Roger. 1997. Historical Linguistics and Language Change. Cambridge: Cambridge UP.

Ledo-Lemos, Francisco. 2000. Feminimum Genus. A Study on the Origins of the IndoEuropean Feminine Grammatical Gender. Munich: Lincom Europa.

L’Homme, Ilona. 2007. “’Nöies’ és ‘férfias’ a 20. Század elsö felének irodalomkritikai diszkurzusában.” In Erzsébet Barát \& Klara Sándor, eds. A nö helye a Magyar nyelvhasználatban. Nyelv, ideologia, média konferencia 2005, szeptember 8-9. Szeged: JATE Press: 131-44.

Lilly, William, John Colet, et al. A shorte introduction of grammar generally to be vsed: compiled and sette forth for the bringing up of all those that intende to attaine the knowleddge of the Latine tongue. London, 1567.

Livia, Anna. 2001. Pronoun Envy: Literary Uses of Linguistic Gender. New York: Oxford UP.

Martinet, André. 1956. “Le genre femenin en indo-europén.” Bulletin de la societé de linguistique de Paris 52: 83-95.

Matasovic, Ranko. 2004. Gender in Indo-European. Heidelberg: Uniersitätsverlag.

Mikkola, Mari. 2008. "Feminist Perspectives on Sex and Gender." Stanford Encyclopedia of Philosophy. Edward N. Zala, ed. http://plato.stanford.edu/entries/feminismgender/

Mirkovic, Jelena, Maryellen C. MacDonald, \& Mark S. Seidenberg. 2005. "Where Does Gender Come From? Evidence from a Complex Inflectional System.” Language and Cognitive Processes 20.1-2: 139-167.

Mühlerhäuser, Peter \& Rom Harré. 1990. "He, She, or It: The Enigma of Grammar and Gender.” In id. Eds. Pronouns and People: The Linguistic Construction of Social and Personal Identity. Oxford: Basil Blackwell, 228-247.

Nagy, Marcell \& Viviana Patti. 2006. "Lexical Gender in Hungarian: Reflections of Social Structures in an Electronic Corpus.” In Eva Maria Thüne, Simona Leonardi, \& Carla Bazzanella, eds. Gender, Language and New Literacy. New York: Continuum Press: 182-195.

Niedzielski, Nancy Anne. 1992. "The Masculine Pronouns as Generic: A View from the Child.” In Kira Hall et al, eds. Locating Power. Proceedings of the Second 
Berkeley Women and Language Conference,II. Berkeley: Berkeley Women and Language Group: 441-446.

Nissen, Uwe Kjaer. 1986. "Sex and Gender Specification in Spanish.” Journal of Pragmatics 10: 725-738.

Percival, W. Keith. 1981. “Sex and Gender in Natural Languages.” Kansas Working Papers in Linguistics 6: 1-16 http://kuscholarworks.ku.edu/dspace/bitstream/1808/551/1/ling.wp.v6.n1.paper1. pdf

Perissinotto, Giorgio. 1983. “Spanish ‘hombre:' Generic or Specific?”Hispania 66.4: 581-586.

Pete, István. 2000. “Ferfinyelv-e a magyar?” Magyar nyelvőr 124: 198-115.

Platze, Hans. 2001. "No Sex, Please, We're Anglo-Saxon? On Grammatical Gender in Old English.” View[z]: Vienna English Working Papers 10: 34-47.

Pusch, Luise F. 1984. Das Deutsche als Männersprache: Aufsätze und Glossen zur Feministischen Linguistik. Frankfurt am Main: Suhrkamp.

Radics, Viktoria. 2007. "Tyúkpasztás angyalhajsza. Lovas Ildikó: Spanyol menyasszony. Lány. Regény.” Litera http://www.litera.hu/hirek/tyukkopasztas-angyalhajsza

Ramo, Sara \& Debi Robertson. 2010. "What Constrains Grammatial Gender Effects on Semantic Judgment? Evidene from Portuguese.” Journal of Cognitive Psychology 23.1: 1-16.

Romaine, Suzanne. 2001. “A Corpus-Based View of Gender in British and American English.” In Marlis Hellinger, eds. Gender Across Languages. Studies in Language and Society 9. Amsterdam: John Benjamins: 153-178.

Romaine, Suzanne. 1997. “Gender, Grammar, and the Space in Between.” In Helga Kotthoff \& Ruth Wodak eds. Communicating Gender in Context. Amsterdam: John Benjamins: 52-76. Repr. In Susan Romaine. 1999. Communicating Gender. Mahwah: Erlbaum: 65-90.

Royen, Gerlach. 1929. Die nominales Klassifikationssysteme in den Sprachen der Erde. Mödling bei Wien: Anthropos.

Rubin, Gayle. 1975. "The Traffic in Women: Notes on the Political Economy of Sex.” Towards an Anthropology of Women. Reyna Reiter, ed. New York: Monthly Review: 770-794.

Sa’ar, Amalia. 2007. “Masculine Talk: On the Subconscious Use of Masculine Linguistic Forms Among Hebrew- and Arabic-Speaking Women in Israel.” Signs: Journal of Women in Culture and Society 32.2: 405-429.

Sabatini, Alma. 1985. “Occupational Titles in Italian: Changing the Sexist Usage.” In Marlis Hellingerd, ed. Sprachwandel und feministische Sprachpolitik: Internationale Perspektiven. Opladen: Westdeutscher Verlag.

Schulz, Muriel R. 1975 (2000). “The Semantic Derogation of Woman.” In Lucy Burke, Tom Crowley, \& Alan Girvin, ds. The Routledge Language and Cultural Theory Reader. New York: Routlege: 82-91.

Schwink, Frederick W. 2004. The Third Gender. Studies in the Origin of German Grammatical Gender. Heidelberg: Winter Verlag.

Seifart, Frank. 2010. “Nominal Classification.” Language and Linguistic Compass 4: 719-736. 
Silverstein, Michael. 1985. "Language and the Culture of Gender: At the Intersection of Structure, Usage and Ideology.” In E. Mertz. \& R. Parmentier, eds. Semiotic Mediation: Sociocultural and Psychological Perspectives. Orlando FL: Academic P: 219-259.

Spender, Dale. 1980. Man Made Language. London: Routledge \& Kegan Paul.

Tan, Dali. 1990. "Sexism in the Chinese Language." Journal of the National Women's Association 2.3: 635-39.

Tight, Daniel. 2006. “The Relationship Between Perceived Gender in L1 English and Grammatical Gender in L2 Spanish.” In Carol A. Klee \& Timothy L. Face, ed. Selected Proceedings of the Seventh Conference on the Acquisition of Spanish and Portugues as First- and Second Languages. Somervile: Cascadilla Proceedings Project; 149-160.

Trudgill, Peter. 1999. "Language Contact and the Function of Linguistic Gender.” Poznan Studies in Contemporary Linguistics 35: 133-52.

Van Campernolle, Rémi A. "What Do Women Want? Linguistic Equality and the Feminization of Job Titles.” Gender and Language 3.1: 33-52

Vigliotto, Gabriella, David Vinson, Federica Paganelli \& Katharina Dworzynski. 2005. "Grammatical Gender Effects on Cognition: Implications of Language Learning and Language Use.” Journal of Experimental Psychology 134: 501-520.

Wandruszka, Mario. 1969. Sprachen, vergleichbar und unvergleichbar. Munich: R. Piper \& Co., Verlag.

Weber, Bruce. 2009. “Maurice Druon, Prolific Writer, Dies at 90.” New York Times 4/17/09

http://www.nytimes.com/2009/04/16/world/europe/16druon.html?_r=1\&scp=1\&s q=Maurice\%20Druon\%20Prolific\%20writer\%20dies\&st=cse

Weigel, Sigrid. 1990. Topographien der Geschlechter. Kulturgeschichtliche Studien zur Literatur. Rembeck bei Hamburg: Rowohl.

Wienold, Götz. 1967. Genus und Semantik. Weisenheim am Glan: Hain.

Wittig, Monique. “The Mark of Gender.” In Nancy Miller, ed. The Poetics of Gender. New York: Columbia UP: 67-73.

Yaguello Marina, 1978. Les mots et les femmes. Paris: Petit Bibliotheque Payot. 